\title{
The effects of liquid nitrogen treatment on the some physical and mechanical properties of scots pine and oriental spruce wood
}

\author{
Huseyin Yorur $^{\text {a,** }}$, Kadir Kayahan ${ }^{\text {b }}$, Muhammed Nuri Günay ${ }^{\text {a }}$, Suat Altun ${ }^{a}$, Belgin Şeker ${ }^{a}$
}

\begin{abstract}
The wood materials widely used from wood construction sector, urban furniture and interior design to furniture sector are renewable resource. Wood has some disadvantages regarding durability to combustion and biological factors. To increase service life especially in urban furniture are coated and/or impregnated against to fire and biological factors. Thus, the wood materials used in construction sector should be treated with fire-retardant chemicals. In this study; Scots pine and Oriental spruce wood materials were exposed to liquid nitrogen for 30 minutes before impregnated with Firetex by using pressure-vacuum method. According to the results, amount of retention in Oriental spruce and Scots pine samples have been increased with liquid nitrogen treatment. Additionally, it was seen that the liquid nitrogen operation had not significant adverse effect on the mechanical properties. Therefore, the liquid nitrogen treatment can apply effectively as a method to improve the impregnability of the wood.
\end{abstract}

Keywords: Impregnation, Retention, Nitrogen, Firetex, Mechanical strength

\section{Sarıçam ve doğu ladini odunlarının bazı fiziksel ve mekaniksel özellikleri üzerine sıvı azot işleminin etkileri}

\begin{abstract}
Özet: Ağaç malzeme, ahşap yapı sektörü, kent mobilyası ve iç mekân tasarımından mobilya sektörüne kadar yaygın olarak kullanılan yenilenebilir bir kaynaktır. Ağaç malzeme, yanma ve biyolojik faktörlere dayanım açısından bazı olumsuz özelliklere sahiptir. Özellikle ahşap yapı ve kent mobilyalarında kullanılan ağaç malzemeler, ürünün ömrünü uzatmak için yanmaya ve biyolojik faktörlere karşı kaplanır ve/veya emprenye edilir. Emprenye işleminde retensiyonun arttırılması yanmaya karşı dayanımı da arttırır. Bu çalışmada sıvı nitrojen uygulamasının retensiyona etkisi incelenmiştir. Sarıçam ve Doğu ladin odunları vakum-basınç metoduyla firetex ile emprenye işlemi öncesi 30 dakika süreyle sıvı nitrojene maruz bırakılmıştır. Sonuçlara göre retensiyon miktarı, doğu ladini ve sarıçam örneklerinde sıvı nitrojen uygulaması ile arttırılmıştır. Ayrıca, sıvı azotun mekanik özellikler üzerinde önemli bir olumsuz etkisi olmadığı görülmüştür. Bu nedenle, sıvı azot muamelesi, odunun emprenye edilebilirliğini iyileştirmek için etkili bir yöntem olarak uygulanabilir.

Anahtar kelimeler: Emprenye, Retensiyon, Azot, Firetex, Mekanik mukavemet
\end{abstract}

\section{Introduction}

Wood is a good renewable material. But, when wood is used in outdoor conditions, it can be exposed to fire, biological and insecticidal deterioration. It is necessary to modify the preservative substances against these adverse conditions. Since the past years, most studies have been carried out by treating with various chemicals to protract the lifetime of wood materials (Hill, 2007). The researcher reached very significant results about impregnated substances such as Tanalith E, Wolmanit, Protim-WR 235, creosote, Borax, CCA (copper, chrome, arsenic) and PCP (pentachlorophenol) (Baysal, 2003; Bozkurt et al., 1993; Yalınkılıç, 1997; Temiz et al., 2005; Uysal et al., 2013; Yorur et al., 2014; Perçin et al., 2015). Firetex is a waterbased fire-resistant agent which it consists of mineral formula of limestone and it isn't any adverse effect on the humans and the animals. Also, it is reported that firetex can be used to increase resistance to against combustion of wood materials (Kesik et al., 2015; Özcan et al., 2016;
Tomak et al., 2013). These substances can be implemented by physical, chemical and biological modification methods applied to wood materials (Hill, 2007). However, in the treatment with chemical substances requires deep and homogeneous distribution. This is related to the high permeability of the wood material (Durmaz et al., 2015; Hill, 2007).

The permeability of wood is influenced by many factors such as sapwood, latewood and heartwood, density, rays, tracheids, resins, and bordered pits. These factors associated with flow path of fluid and the anatomical structure in wood (Flynn, 1995). All wood species are not possible as equal to impregnate. Impregnation of some wood species is easy, but the others are difficult (Bozkurt et al., 1993). Spruce is a wood species of refractory impregnated (Panek et al., 2013). One of the most important reasons for this is the occurrence of pit aspiration in softwoods. Pit aspiration closes off the porous by torus move across, thus prevent fluid flow through the pit (Petty, 1972). In the most of studies have said that the bordered pit is the main factors on the

\footnotetext{
$凶 \quad$ a Karabük University, Faculty of Forestry, Forest Industry Engineering Department, Karabük, Turkey

b Bartın University, Vocational High School, Material and Material Processing Technologies Department, Bartın, Turkey

@ * Corresponding author (İletişim yazarı): huseyinyorur@karabuk.edu.tr

$\checkmark \quad$ Received (Geliş tarihi): 03.10.2017, Accepted (Kabul tarihi): 14.12.2017
}

Citation (Atıf): Yörür, H., Kayahan, K., Günay, M.N., Altun, S., Şeker, B., 2017. The effects of liquid nitrogen treatment on the some physical and mechanical properties of scots pine and oriental spruce wood. Turkish Journal of Forestry, 18(4): 309-313. DOI: $10.18182 / \mathrm{tjf} .341516$ 
permeability of softwoods (Erickson, 1970; Keith et al., 1988; Kuroda et al., 1988).

Alternative methods have been still researched due to the challenges confronted in impregnation process and increasing amount of retention. To develop liquid flow of permeability have been applied four different methods biological, chemical, mechanical, and physical treatments, such as drying, steam, incising, and vacuum pressure treatment (Mai et al., 2004; Yildiz et al., 2012; Panek et al., 2013; He et al., 2014). It has not been detected any study on the cryogenic treatment to increase permeability or impregnability of wood. Therefore, this study examined the effects of liquid nitrogen (LN) on wood properties. The liquid nitrogen $\left(-196^{\circ} \mathrm{C}\right)$ is widely used at lower temperature applications such as freezing of living tissue and drying of food products. When the wood which has high MC (moisture content), is cooled under the freezing point, the ice is formed in the cell lumens. Expanding volume of the ice causes shrinkage (Jiang, 2008) and a physical damage in the cell wall (Zhao et al., 2015). It is envisaged that this effect of $\mathrm{LN}$ increases the impregnation retention. Therefore, it was aimed to increase the amount of retention of impregnation chemical by using $\mathrm{LN}$ in this study. For this purpose, experimental wood samples were exposed to LN before impregnation processes and the effect of $\mathrm{LN}$ on the retention and some physical and mechanical properties of wood material were investigated.

\section{Materials and methods}

\subsection{Material}

Oriental spruce (Picea orientalis) and Scots pine (Pinus sylvestris) wood materials were chosen from timber suppliers of Karabuk, Turkey. A special emphasis was put on the selection of the wood material. The experimental samples were selected from the wood materials, which nondeficient, whole, knotless, normally gown (without zone line, reaction wood, decay, insect or fungal infection. $20 \%$ solution of Firetex was used as impregnation. The physical properties of firetex in the Table 1 (Özcan et al., 2016) and ICP AES analysis in the Table 2 (Balıkesir University, Basic Sciences Application and Research Center, 2004) were given.

Table 1. Physical properties of firetex

\begin{tabular}{ll}
\hline Density & $1.035 \mathrm{~g} / \mathrm{cm}^{3}$ \\
\hline Boiling point & $98^{\circ} \mathrm{C}$ \\
\hline Freezing point & $-3{ }^{\circ} \mathrm{C}$ \\
\hline $\mathrm{pH}$ & 3,7 \\
\hline TDS & $739 \mathrm{ppm}$ \\
\hline Evaporation & $\left(60^{\circ} \mathrm{C} / 24 \mathrm{~h}\right) \% 50$ \\
\hline
\end{tabular}

Table 2. ICP AES analysis results of firetex

\begin{tabular}{llll}
\hline $\mathrm{Ba}$ & $0,368 \mathrm{mg} / \mathrm{L}$ & $\mathrm{Zn}$ & $<10 \mu \mathrm{g} / \mathrm{L}$ \\
\hline $\mathrm{Cd}$ & $<1 \mu \mathrm{g} / \mathrm{L}$ & $\mathrm{Mn}$ & $<1 \mu \mathrm{g} / \mathrm{L}$ \\
\hline $\mathrm{Ni}$ & $0,012 \mathrm{mg} / \mathrm{L}$ & $\mathrm{Cr}$ & $<2 \mu \mathrm{g} / \mathrm{L}$ \\
\hline $\mathrm{Mg}$ & $4,25 \mathrm{mg} / \mathrm{L}$ & $\mathrm{Co}$ & $<0,5 \mu \mathrm{g} / \mathrm{L}$ \\
\hline $\mathrm{Fe}$ & $<5 \mu \mathrm{g} / \mathrm{L}$ & $\mathrm{Hg}$ & $<5 \mu \mathrm{g} / \mathrm{L}$ \\
\hline $\mathrm{Pb}$ & $<5 \mu \mathrm{g} / \mathrm{L}$ & $\mathrm{As}$ & $<0,5 \mu \mathrm{g} / \mathrm{L}$ \\
\hline $\mathrm{Cu}$ & $<1 \mu \mathrm{g} / \mathrm{L}$ & & \\
\hline
\end{tabular}

\subsection{Method}

\subsubsection{The determination of moisture content}

The moisture content before and after treatment of the woods used in the preparation of the test samples was determined according to TS 2471. Moisture content (r):

$$
r=\frac{M r-M o}{M o} \times 100
$$

Where $\mathrm{Mr}$ is the moist weight and Mo is the oven dry weight $(\mathrm{g})$.

\subsubsection{Determination of density}

The densities before and after treatment of the woods used in the preparation of the test samples were determined according to TS 2472 . Accordingly, density $\delta\left(\mathrm{g} / \mathrm{cm}^{3}\right)$ was calculated with the following equation:

$$
\delta=\frac{M}{V}
$$

Where $\mathrm{M}$ is the weight $(\mathrm{g})$ and $\mathrm{V}$ is the volume $\left(\mathrm{cm}^{3}\right)$ of wood.

\subsubsection{Preparation of experiment specimens}

The samples were at air-dry state before impregnation. LN was applied to the test samples by dipping in a closed chambers for 30 minutes as a first stage of impregnation. At the second stage, they were hold in sunless environment for 1 week. At the third stage, samples were placed in the impregnation chambers and after the pre-vacuum period (620 mbar, $30 \mathrm{~min}$ ), the impregnating solution was filled into chamber until the samples were covered. Then the pressure period was carried out under 2 bar for 60 minutes. After pressure period, impregnation solution unloaded and a final vacuum was applied. Between the stages, all the samples were weighed on an analytic balance with $\pm 0.001 \mathrm{~g}$ sensitivity.

Retention $\left(\mathrm{R}, \mathrm{kg} / \mathrm{m}^{3}\right)$ was calculated from the equations of (ASTM D 1413-07 2007);

$$
R=\frac{G . C}{V} \cdot 10 \mathrm{~kg} / \mathrm{m}^{3}
$$

where;

G: The amount of solution absorbed by wood sample (g)

V: The volume of wood sample $\left(\mathrm{cm}^{3}\right)$

$\mathrm{C}$ : The concentration of solution $(\%)$

$\mathrm{G}=\mathrm{T}_{2}-\mathrm{T}_{1}, \mathrm{~T}_{1}$ : weight of wood sample before impregnation $(\mathrm{g}), \mathrm{T}_{2}$ : weight after impregnation $(\mathrm{g})$.

Air-dry densities of the wood samples were determined according to TS 2472. Mechanical properties were determined according to relevant standards. Bending resistance (TS 2474, 1976), bending modulus of elasticity (TS 2478, 1976), compression strength parallel to gain (TS $2595,1976)$ and impact strength (TS 2477, 1976) were determined. 


\section{Result and discussion}

\subsection{Physical properties}

Air-dry densities and the moisture content (MC) of the samples were given in the Table 3. There was increase in density compared to the control samples. However, changes of density may be due to the physical properties of wood were destroyed after LN implement. Destroyed bordered pits led the increase of retention of impregnation solution. Thus, higher retention increased the density, slightly.

When the similar studies were examined, it was seen that the density of wood increased with impregnation. Örs, et al., (1999) reported that impregnated samples were higher values of oven-dried and air-dried density than control samples. LN treatment also decreased the MC of the samples slightly.

When the results, given in Table 4, on the amount of retention were examined, it was observed that the LN increased the amount of retention compared to the control samples. Retention increase was found as $15.6 \%$ in the pine and $16.9 \%$ in the spruce pre-treated with LN. This status supports the hypothesis that the expanding volumes of the frozen liquids increase the impregnability of wood.

Previous studies on the bordered pits reported that an increase amounts of retention by microwave (Torgovnikov et al., 2009; He et al., 2014), bioincising (Schwarze et al., 2006; Lehringer et al., 2009) and with enzymatic treatment (Maschek et al., 2013; Durmaz et al., 2015). So, this increase of retention obtained may have caused by the effect of $\mathrm{LN}$ on the bordered pits. Effect on wood of $\mathrm{LN}$ can interpret as; LN treatment increased the penetration of impregnate into the wood. Retention of firetex in Uludag fir was reported as $36.1 \mathrm{~kg} / \mathrm{m}^{3}$ by Özcan et al., 2016. It seems higher than that of this study but, the size of the samples was quite small and the impregnation time was very long $(24 \mathrm{~h})$ in that study. So, this difference was probably due to inequality impregnation conditions.

Table 3. Densities of Oriental spruce and Scots pine.

\begin{tabular}{cccccc}
\hline & \multicolumn{5}{c}{ Air dried } \\
\cline { 2 - 6 } & $\begin{array}{c}\text { Before } \\
\text { treatment } \\
\text { moisture } \\
\text { content } \\
{[\%]}\end{array}$ & $\begin{array}{c}\text { After } \\
\text { treatment } \\
\text { moisture } \\
{\left[\mathrm{g} / \mathrm{cm}^{3}\right]}\end{array}$ & $\begin{array}{c}\text { LN and } \\
\text { content } \\
{[\%]}\end{array}$ & $\begin{array}{c}\text { After } \\
\text { impregnated } \\
{\left[\mathrm{g} / \mathrm{cm}^{3}\right]}\end{array}$ & $\begin{array}{c}\text { treatment } \\
\text { moisture } \\
\text { content } \\
{[\%]}\end{array}$ \\
\hline $\begin{array}{c}\text { Oriental } \\
\text { Spruce }\end{array}$ & 10.8 & $\begin{array}{c}0.43 \\
(0.07)\end{array}$ & 11.6 & $\begin{array}{c}0.45 \\
(0.05)\end{array}$ & 11.2 \\
\hline $\begin{array}{c}\text { Scots } \\
\text { pine }\end{array}$ & 8.9 & $\begin{array}{c}0.55 \\
(0.03)\end{array}$ & 10.7 & $\begin{array}{c}0.56 \\
(0.07)\end{array}$ & 10.3 \\
* Values in parentheses are standard deviation & & \\
\hline
\end{tabular}

Table 4. Amounts of retention of Oriental spruce and Scots pine

\begin{tabular}{lccc}
\hline & \multicolumn{3}{c}{ Retention $\left[\mathrm{kg} / \mathrm{m}^{3}\right]$} \\
\cline { 2 - 4 } & Impreg. & LN and Impreg. & Change [\%] \\
\hline Oriental & 19.91 & 23.28 & 16.9 \\
Spruce & $(3.75)$ & $(3.01)$ & 15.6 \\
\hline \multirow{2}{*}{ Scotch pine } & $\begin{array}{l}13.85 \\
(2.46)\end{array}$ & $\begin{array}{l}16.02 \\
(2.21)\end{array}$ & \multirow{2}{*}{ * }
\end{tabular}

*Values in parentheses are standard deviation
Relatively small sample sizes and long impregnation time must have caused higher retention. In parallel with this claim, Tomak and Cavdar (2013) obtained higher retention by using higher concentration of firetex and reported higher fire resistance. But in this study retention increase were achieved by using LN treatment instead of increasing concentration. Higher retention ratio was obtained with the same concentration of the fire retardants. By this way consumption of the chemicals can be decreased.

\subsection{Mechanical properties}

The mechanical test results were given in the Table 5 . According to the results, all the mechanical properties of pine were affected negatively by the LN treatment. In the literature, Breyer (1993) reported that the loss of resistance caused by water-soluble preservative related directly to chemical content and difficulty of fixation/precipitation of its.

Kollman (1968) reported that there was a decrease slightly in the bending and the impact bending strength, but an increase in the compression strength of pine and spruce wooden mine timber impregnated with water-soluble salts. Tetjamer (1986) reported that zinc chloride and sulphate impregnation did not cause a significant loss in the compression strength and the bending modulus of elasticity of pine, larch and spruce woods This can be explained that mechanical properties decrease with the increasing impregnation materials in wood. But, in the case of spruce wood, compression strength, bending strength and modulus of elasticity were increased while the impact bending strength was decrease. It was reported by Özçifçi et al., (2007) that except for Scots pine, the modulus of elasticity in bending increased with the higher retention amount of the impregnation material. The effect of $\mathrm{LN}$ was different on the wood samples used in this study. Scots pine was affected more negatively than spruce. Because of higher permeability of Scots pine, LN penetrated easily and deeper, thus destructive effects of the LN on the cell wall may have been higher than that of Oriental spruce. Also, larger resin canals and thinner walls of the epithelial cells of the Scots pine could have been contributing this effect.

Table 5. Mechanical properties after impregnation

\begin{tabular}{lcccc} 
& \multicolumn{2}{c}{ Oriental Spruce } & \multicolumn{2}{c}{ Scotch pine } \\
\cline { 2 - 5 } & Impreg. & $\begin{array}{l}\text { LN and } \\
\text { Impreg. }\end{array}$ & Impreg. & $\begin{array}{l}\text { LN and } \\
\text { Impreg. }\end{array}$ \\
\hline Compression strength // & 48.51 & 55.67 & 66.72 & 61.36 \\
{$\left[\mathrm{~N} / \mathrm{mm}^{2}\right]$} & $(2.69)$ & $(2.13)$ & $(1.37)$ & $(2.02)$ \\
\hline Bending resistance & 81.71 & 83.19 & 101.37 & 96.51 \\
{$\left[\mathrm{~N} / \mathrm{mm}^{2}\right]$} & $(2.26)$ & $(1.77)$ & $(2.85)$ & $(2.33)$ \\
\hline Modulus of Elasticity & 8781.45 & 9358.55 & 10644.85 & 10005.97 \\
{$\left[\mathrm{~N} / \mathrm{mm}^{2}\right]$} & $(535.95)$ & $(372.26)$ & $(562.70)$ & $(573.65)$ \\
\hline Impact Bending & 0.32 & 0.28 & 0.43 & 0.38 \\
Strength [kg.m/cm $\left.{ }^{2}\right]$ & $(0.05)$ & $(0.01)$ & $(0.02)$ & $(0.04)$ \\
\hline
\end{tabular}

${ }^{*}$ Values in parentheses are standard deviation 


\section{Conclusions}

In this study, it was determined that treatment of spruce and pine samples with $\mathrm{LN}$ caused to increase in amounts of retention. It can be said that the impregnation solution penetrated deeper because of damaging the pits by LN treatment. Increase in retention of firetex leads increase in the fire retarding effect of it. LN treatment decreased mechanical properties slightly in Scots pine but increased in spruce. So, it can be said that LN had not a significant adverse effect on the mechanical properties. Thus, it can be increase the use of wooden products. Consequently, the LN treatment can apply effectively as a method, which is simple to use, easy to produce and economical, to improve the impregnability of the wood.

\section{References}

ASTM-D 1413-07, 2007. Standard test method of testing wood preservatives by laboratory soil-block cultures. Annual Book of ASTM Standards, ASTM Standards, West Conshohocken, PA, USA.

Balıkesir University., 2004. Basic Sciences Application and Research Center, Test Report, No: 4.

Baysal, E., 2003. Fire properties of Beech wood impregnated with fire retardants and natural extractives. Firat University, Journal of Science and Engineering, 15(1): 163-174.

Bozkurt, A.Y., Göker, Y., Erdin, N., 1993. Emprenye Tekniği. İstanbul Üniversitesi Orman Fakültesi Yayınlar1, 3779/425.

Breyer, D.E., 1993. Design of Wood Structures. New York, USA: McGaw Hill, Inc.; 902p. ISBN 0-07-007678-2.

Durmaz, S., Yildiz, U.C., Yildiz, S., 2015. Alkaline enzyme treatment of spruce wood to increase permeability. BioResources, 10(3):4403-4410.

Erickson, H.D., 1970. Permeability of southern pine woodA review. Wood Science, 2(3): 149-158.

Flynn, K.A., 1995. A review of the permeability, fluid flow, and anatomy of spruce (Picea spp.). Wood Fiber Sci., 27(3): 278-284.

He, S., Lin, L., Fu, F., Zhou, Y., Fan, M., 2014. Microwave treatment for enhancing the liquid permeability of Chinese fir. BioResources, 9(2): 1924-1938.

Hill, C.A. 2007. Wood Modification: Chemical, Thermal and Other Processes. John Wiley \& Sons, England

Jiang, J.L., Lu, J.X., 2008. Dynamic viscoelasticity of wood after various drying processes. Drying Technology, 26(5): 537-543.

Keith. C.T., Chauret, G., 1988. Anatomical studies of CCA penetration associated with conventional (tooth) and with micro (needle) incising. Wood Fiber Sci., 20(2): 197-208.

Kesik, H.İ., Aydoğan, H., Çağatay, K., Özkan, O.E., Maraz, E., 2015. Fire Properties of Scots Pine Impregnated with Firetex. ICOEST International Conference on Environmental Science and Technology, Sarajevo, BH.

Kollman, F., 1968. Principles of Wood Science and Technology: Solid wood. Springer-Verlag Berlin.

Kurodan, N., Siau, J.F., 1988. Evidence of nonlinear flow in softwoods from wood permeability measurements. Wood Fiber Sci., 20(1): 162-169.
Maschek, D., Goodell, B., Jellison, J., Lessard, M., Militz, H., 2013. A new approach for the study of the chemical composition of bordered pit membranes: 4pi and confocal laser scanning microscopy. American Journal of Botany 100(9): 1751- 1756. DOI: 10.3732/ajb.1300004

Örs, Y., Atar, M., Peker, H., 1999. Bazı emprenye maddelerinin sarıçam ve Doğu kayını odunlarının yoğunluklarına etkileri. Doğa Türk Tarım ve Ormancılık Dergisi, 23(5): 1169-1179.

Özcan, C., Kurt, Ş., Esen, R., Korkmaz, M., 2016. The determinate combustion properties of fir wood impregnated with fire-retardants. The Online Journal of Science and Technology-July, 6(3).

Özçifçi, A., Örs, Y., Uysal, B., 2007. Determination of some physical and mechanical properties of laminated veneer lumber impregnated with boron compounds. Journal of Applied Polymer Science, 105: 2218-2224.

Panek, M., Reinprecht, L., Mamonova, M., 2013. Trichoderma viride for Improving Spruce Wood Impregnability. BioResources, 8(2):1731-1746. DOI: 10.15376/biores.8.2.1731-1746

Petty, J.A., 1972. The aspiration of bordered pits in conifer wood. Proc. R. Soc. Lond. B Biol. Sci., 181: 395 - 406.

Perçin, O., Sofuoglu, S.D., Uzun, O., 2015. Effects of boron impregnation and heat treatment on some mechanical properties of oak (Quercus petraea Liebl.) wood. BioResources, 10(3), 3963-3978.

Schwarze, F., Landmesser, H., Zgaggen, B., Heeb, M., 2006. Permeability changes in heartwood of Picea abies and Abies alba induced by incubation with Physisporinus vitreus. Holzforschung 60(4):450 - 454.

Temiz, A., Yildiz, U.C., Nilsson, T., 2006. Comparison of copper emission rates from wood treated with different preservatives to the environment. Building and Environment, 41(7): 910-914.

Tetjamer, L., 1986. Methoden und resultate der prüfung schweizerischen bahvolzer. Materialprüfungsaf Schweizerischen Polytechnikum, Paul Paray Verlag, Zurich.

Tomak, E.D., Cavdar, A.D., 2013. Limited oxygen index levels of impregnated Scots pine wood. Thermochimica acta, 573: 181-185.

Torgovnikov, G., Vinden, P., 2009. High intensity microwave wood modification for increasing permeability. For. Prod. J., 59(4): 84-92.

TS 2472, 1976. Wood-determination of density for physical and mechanical tests, Institute of Turkish Standards.

TS 2474, 1976. Wood-determination of ultimate strength in static bending, Institute of Turkish Standards.

TS 2477, 1976. Wood-determination of impact bending strength, Institute of Turkish Standards.

TS 2478, 1976. Wood-determination of modulus of elasticity in static bending, Institute of Turkish Standards.

TS 2595, 1976. Wood-determination of ultimate stress in compression parallel to grain, Institute of Turkish Standards.

Uysal, B., Yorur, H., 2013. The effect of steam treatment on bonding strength of impregnated wood materials. Journal of Adhesion Science and Technology, 27(8): 896-904. 
Wardrop, A.B., Davies, G.W., 1961. Morphological factors relating to the penetration of liquids into wood. Holzforschung, 15(5): 129- 140.

Yalınkılıç, M.K., Baysal, E., Demirci, Z., 1997. Fire resistance of Calabrian pine (Pinus brutia Ten.) wood treated with some boron compounds and/or water repellents. Turkish Journal of Agiculture and Forestry, 21(5): 423- 431.
Yorur, H, Kurt, Ş, Uysal B., 2014. Bonding strength of oak with different adhesives after humid - water - heat tests. Journal of Adhesion Science and Technology, 28(7): 690-701.

Zhao, L., Lu, J., Zhou, Y., Jiang, J., 2015. Effect of low temperature cyclic treatments on modulus of elasticity of birch wood. BioResources 10(2): 2318-2327. 